\title{
Doğrudan Yabancı Yatırım Girişlerinin İhracat Üzerine Etkileri: Türkiye Örneği
} (Araştırma Makalesi)

\author{
The Effects of Inward Foreign Direct Investment on Exports: The Case of \\ Turkey \\ Doi: 10.29023/alanyaakademik.1021253
}

\section{Burak UĞUR}

Arş.Gör. Dr. Kahramanmaraş Sütçü İmam Üniversitesi, İktisadi ve İdari Bilimler Fakültesi, burakugur89@hotmail.com,

Orcid No: 0000-0001-9056-8035.

\section{Seyhan TAŞ}

Prof. Dr. Kahramanmaraş Sütçü İmam Üniversitesi, İktisadi ve İdari Bilimler Fakültesi, seyhantas1@hotmail.com,

Orcid No: 0000-0002-9671-4838.

Bu makaleye atıfta bulunmak için: Uğur, B. \& Taş, S. (2022). "Doğrudan Yabancı Yatırım Girişlerinin İhracat Üzerine Etkileri: Türkiye Örneği”, Alanya Akademik Bakış, 6(1), Sayfa No. 18691889.

\author{
Anahtar kelimeler: \\ Türkiye, Doğrudan \\ Yabancı Yatırım, \\ Ihracat.
}

Makale Geliş Tarihi: 09.11.2021

Kabul Tarihi:

24.01.2022

Keywords:

Turkey, Foreign

Direct Investment, Export.

\section{ÖZET}

$\overline{\text { Doğrudan yabancı yatırım yoluyla ihracatın artması hükümetlerin doğrudan }}$ yatırım girişini teşvik etmelerinin en önemli nedenleri arasındadır. Doğrudan yabancı yatırım girişlerinin ev sahibi ülkenin ihracatı üzerindeki pozitif etkisi ürünün yaşam evreleri modeli, uçan kazlar modeli ve yeni büyüme teorileri ile izah edilmektedir. 2008 küresel krizinin ardından Türkiye ekonomisi dâhil olmak üzere dünya ekonomisinin genelinde başlayan doğrudan yabancı yatırım ve ihracattaki istikrarsızlıklar günümüzde de devam etmektedir. Bu durumdan hareketle Türkiye ekonomisinde doğrudan yabanci yatırım girişlerinin ihracat üzerindeki uzun dönemli etkisinin belirlenmesi oldukça önemli bir hale gelmiştir. Bu çalışmada, Türkiye ekonomisi için 1980-2019 yılları arasında doğrudan yatırım girişlerinin ihracat üzerindeki etkisi eşbütünleşme ve nedensellik analizleriyle tahmin edilmiştir. Analizler sonucu elde edilen bulgular, Türkiye ekonomisinde doğrudan yabancı yatırım girişlerinin ihracat üzerinde pozitif etkili olduğunu göstermektedir.

\section{ABSTRACT}

The increase in exports through foreign direct investment is one of the most important reasons among governments' desire to attract direct investment. The positive effect of direct investment inflows on the export performance of the host country is explained by the product life cycle, the flying geese model and new growth theories. After the 2008 global crisis, the instabilities in foreign direct investment and exports that started throughout the world economy, including the Turkish economy, continue today. Based on this situation, it has become very important to determine the long-term effect of 
inward foreign direct investment on exports in the Turkish economy. In this study, the effect of inward foreign direct investment on exports for the Turkish economy between 1980 and 2019 was estimated by cointegration and casuality methods. The findings obtained as a result of the analysis show that inward foreign direct investment have a positive effect on export in the Turkish economy.

\section{GíRIŞ}

Doğrudan yabancı yatırım (DYY), bir şirketin yabancı bir ülkede yeni bir şirket kurması ya da hâlihazırdaki şirketi satın alması ve birleşmesi yoluyla oluşan ve beraberinde teknoloji, girişimcilik, know-how (teknik bilgi), pazarlama ve ihracat bilgisi gibi konularda önemli olanaklar sağlayan uzun dönemli yatırımlardır (Karluk, 2013: 756).

Doğrudan yatırımı artırmaya yönelik politikaların temel amacı daha yüksek büyüme hızına ulaşmak olmakla beraber, bu amacın meydana gelme yollarından biri de ihracattır. Doğrudan yatırım ev sahibi ekonominin ihracatını; sermaye, know how, yönetim bilgisi, teknoloji ve özellikle küresel piyasalara erişimi sağlayarak genişletmektedir (Bozdalığlu, 2010: 256).

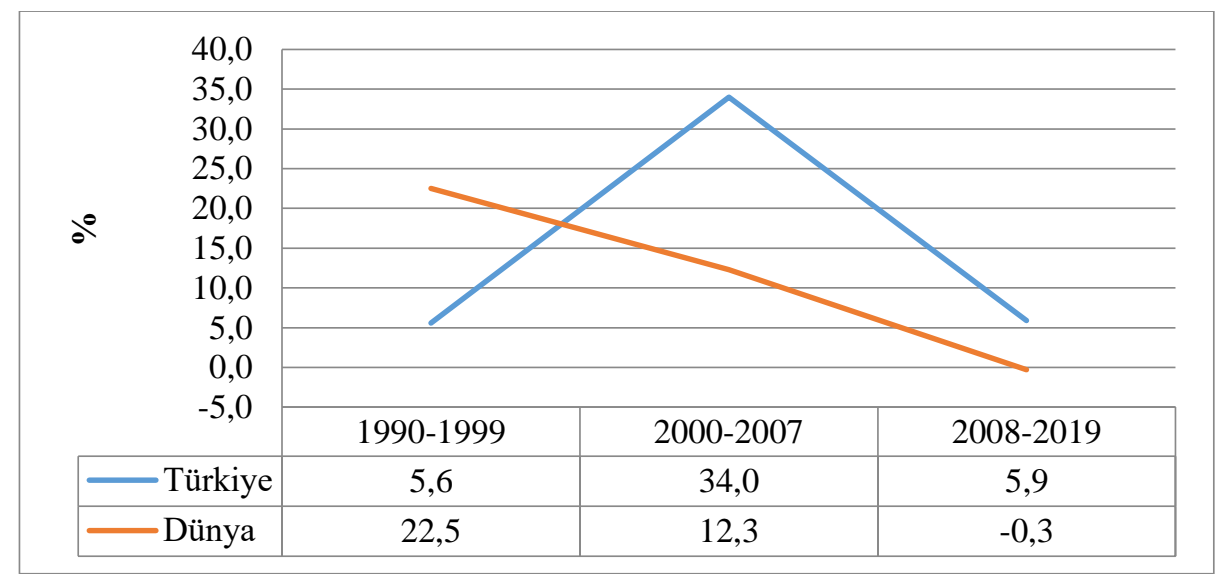

Şekil 1. Dünya'daki ve Türkiye'deki Doğrudan Yabancı Yatırımdaki Ortalama Büyüme Oranları (1990-2019, \%, Akım)

Kaynak: UNCTAD, 17.09.2021.

Şekil 1'de dünyadaki ve Türkiye'deki doğrudan yabancı yatırımdaki ortalama büyüme oranları gösterilmektedir. Şekil 1'den de görüldüğü üzere Türkiye ekonomisinde 2000'li yılların başından itibaren yakalanan siyasi istikrar, ekonominin büyümesi, yabancı yatırımcılara getirilen kolaylıklar, Avrupa Birliğine girmeye yönelik atılan adımlar ve hızlanan özelleştirme hareketleri yardımıyla Türkiye'ye yönelik doğrudan yatırımlar önemli düzeyde artmıştır. Fakat 2008 'den beri dünya ile paralel olarak Türkiye ekonomisinde de doğrudan yatırımlarda önemli düzeyde bir yavaşlama gözlemlenmektedir. Bu hususun ana sebepleri, 2008 senesinde başlayan ve etkisi çeşitli biçimlerde süren küresel kriz sebebiyle küresel büyümenin zayıf seyretmesi ve uluslararası şirketlerin kârlılıklarındaki düşüşlerdir (UNCTAD, 2019: 14-15). Bununla birlikte küresel gelişmelerin Türkiye ekonomisinde yarattığı reel kurda önemli oranda değer kaybı, 
Avrupa Birliği ile müzakarelerinin yavaşlaması, jeopolitik riskler ve bazı siyasi ve toplumsal olaylar da önemli rol oynamaktadır (Kılınçer, 2019: 83-91).

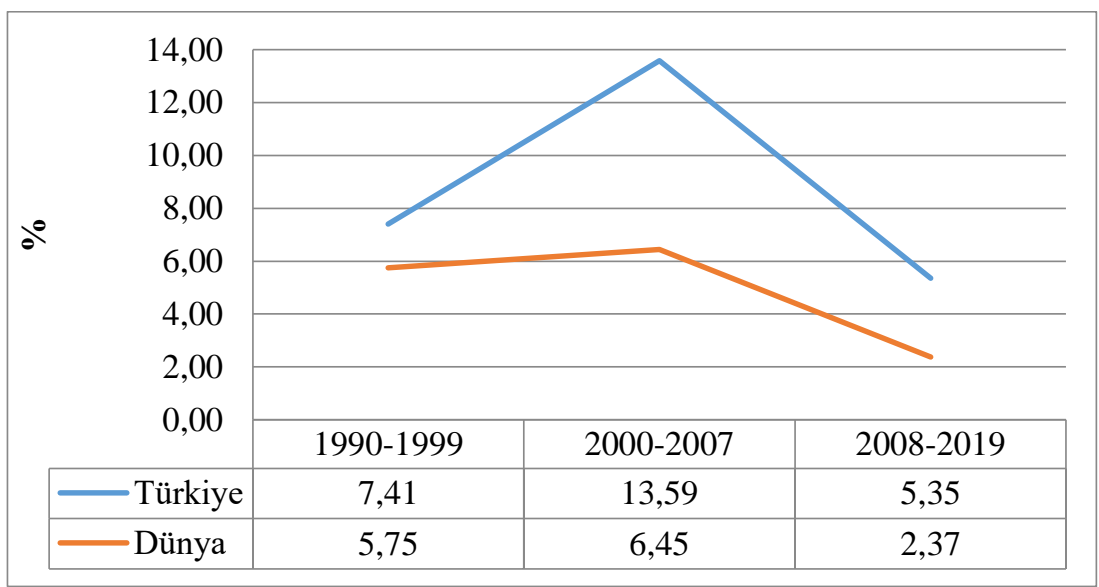

Şekil 2. Dünya'da ve Türkiye'de Mal İhracat Hacmi (Miktarı) Ortalama Büyüme Hızı (19902019, \%)

Kaynak: WTO, 17.09.2021.

Şekil 2'de dünyada ve Türkiye'de mal ihracat hacminin ortalama büyüme hızları gösterilmektedir. Şekil 2'den de görüldügü üzere Türkiye ekonomisinde 2000'li yılların başından itibaren yakalanan ekonomik ve siyasi istikrar, ekonominin büyümesi, artan ihracat destekleri, teknoloji yoğun malların ihracatındaki artış ve ekonomik entegrasyonlarda etkinliğin arttırılmasıyla Türkiye'nin ihracatı ciddi biçimde artmıştır. Fakat dünyada ve Türkiye'de mal ihracat miktarı küresel ekonomik krizin başlangıcından önceki döneme (2007 ve öncesi) kıyasla yavaş bir seyir izlemektedir. Türkiye ekonomisi pazar çeşitlendirmesi yoluyla dünya ekonomisine kıyasla daha az etkilenmesine rağmen, küresel büyümenin zayıf seyretmesi ve ticari korumacılıktaki ciddi artış ihracatı olumsuz etkilemektedir (Kurnaz, 2014: 67).

Doğrudan yatırımın ihracat üzerindeki etkisi ülkelerin ekonomi politikaları açısından çok önemlidir. Bir ekonomide doğrudan yabancı yatırım girişlerinden ihracata doğru bir ilişkinin mevcut olması, ihracatın ve iktisadi büyümenin yükselmesi amacıyla doğrudan yatırım girişlerini teşvik etmeyi gerekli hale getirmektedir (Greenaway, 2004: 1029). 2008 küresel krizinin ardından başlayan doğrudan yabancı yatırım ve ihracattaki istikrarsızlıkların günümüzde de devam etmesi ve Türkiye'de doğrudan yabancı yatırımların diğer gelişmekte olan ülkelere kıyasla nispi serbestleşmesi; Türkiye ekonomisinde doğrudan yabancı yatırım girişlerinin uzun dönemde ihracat üzerindeki etkisinin tespit edilmesini önemli bir hale getirmektedir.

Türkiye ekonomisinde 1980'li yılların başından itibaren yabancı sermaye ve dış ticaret alanlarında liberalleşmeye yönelik uygulamalar yürürlüğe konulmuştur (Gür, 2014: 64). Bu çalışmanın, incelenen dönem (1980-2019) itibarıyla literatüre katkıda bulunacağı öngörülmektedir. Böylece Türkiye ekonomisinde ihracatın arttırabilmesi için doğrudan yatırım girişlerinin rolü yeni dönem verileriyle tespit edilecek ve bu bağlamda politika önerileri sunulabilecektir. 
$\mathrm{Bu}$ çalışmanın amacı, Türkiye ekonomisinde DYY girişlerinin ihracat üzerindeki etkisini incelemektir. Bu bağlamda bu etki, 1980-2019 dönemi verileri çerçevesinde eşbütünleşme ve nedensellik analizleri yardımıyla test edilmektedir. Bunun için modelde, mal ihracatı, stok doğrudan yabancı yatırım girişi ve kontrol değişkeni olarak da reel efektif döviz kuru kullanılmaktadır. Bu kapsamda, ilk olarak konuyla ilgili literatür taramasına yer verilmekte, ardından teorik çerçeve incelenerek, Türkiye'de doğrudan yabancı yatırımların benzer ekonomilere kıyasla seyrine yönelik bilgilere yer verilmektedir. Bu bölümün ardından ekonometrik yöntem üzerinde durulmaktadır. Takip eden bölümde ise ampirik bulgular sunularak sonuçlar ortaya konmaktadır. Son olarak değerlendirmeler yapılarak politika önerileri sunulmakta ve çalışma sonlandırılmaktadır.

\section{LITERATÜR TARAMASI}

Türkiye'de doğrudan yabancı yatırım (DYY) girişlerinin ihracat üzerindeki etkisine yönelik çalışmalar Tablo 1'de aktarılmıştır. Tablo 1'den görüldüğü üzere, DYY girişlerinin ihracat üzerine etkisi zaman serisi (bir ülkeli analizler), panel veri (birden fazla ülkeli analizler) ve meta veri analizleriyle (ampirik literatür özeti) analiz edilmektedir. Ampirik çalışmalarda Türkiye için farklı sonuçların elde edildiği görülmektedir. Bu durum, incelenen döneme, oluşturulan modellere (logaritmik, log-lineer, kübik, kuadratic vb.), DYY'nin stok veya akım olarak kullanılmasına, ihracat değişkenine (mal ve hizmet, mal, imalat sanayi), kontrol değişkenine ve ihracat ve DYY'nin karşılıklı ülkeler arasında ele alınıp alınmamasına göre farklılık sergilemektedir. Tablo 1'den anlaşıldığı üzere, Türkiye'de doğrudan yatırım girişlerinin ihracat üzerine etkisine yönelik çalışmalarda değişkenlerin mutlak olarak alındığ ve 1980-2019 döneminin ele alınmadığ tespit edilmektedir. Tablo 1 incelendiğinde, Türkiye'de doğrudan yatırım girişlerinin ihracat üzerindeki etkisine yönelik ortak bir karar olmadığı görülmektedir. Ampirik bulgulara göre, çalışmaların önemli bir kısmında DYY girişlerinin ihracat üzerine etkisi pozitif ve anlamsız olarak bulunmakla beraber, bazı çalışmalarda negatif bulunmuştur.

Tablo 1. Türkiye’de Doğrudan Yabancı Yatırım Girişlerinin İhracat Üzerindeki Etkisiyle İlgili Çalışmalar

\begin{tabular}{|c|c|c|c|c|}
\hline \begin{tabular}{|l|} 
Yazarlar ve \\
Yillar
\end{tabular} & Dönem ve Ülkeler & Yöntem & Değişkenler & Sonuç \\
\hline $\begin{array}{l}\text { Şen ve Karagöz } \\
(2005)\end{array}$ & $\begin{array}{l}\text { 1994 Q2-2004 Q4 } \\
\text { (çeyreklik), } \\
\text { Türkiye }\end{array}$ & Granger Nedensellik & İhracat, Büyüme ve DYY & $\begin{array}{l}\text { DYY'nin ihracata } \\
\text { herhangi bir etkisi } \\
\text { bulunamamıştır. }\end{array}$ \\
\hline \begin{tabular}{|l|} 
Karagöz ve \\
Karagöz (2009)
\end{tabular} & $\begin{array}{l}\text { 1991 Q1-2003 Q2 } \\
\text { (çeyreklik), } \\
\text { Türkiye }\end{array}$ & $\begin{array}{l}\text { Engle-Granger } \\
\text { Eşbütünleşme Testi } \\
\text { ve Granger } \\
\text { Nedensellik }\end{array}$ & İhracat ve DYY & $\begin{array}{l}\text { DYY'deki bir artışın } \\
\text { ihracat üzerindeki etkisi } \\
\text { anlamsızdır. DYY'den } \\
\text { ihracata doğru } \\
\text { nedensellik yoktur. }\end{array}$ \\
\hline Altıntaş (2009) & $\begin{array}{l}1996 \text { Q1-2007 Q2, } \\
\text { (çeyreklik) Türkiye }\end{array}$ & \begin{tabular}{|l|} 
Johansen- Jelius \\
Eşbütünleşme Testi \\
ve Granger \\
Nedensellik
\end{tabular} & DYY, İhracat ve İthalat & $\begin{array}{l}\text { Uzun vadede ithalat } \\
\text { arttıkça DYY girişinin } \\
\text { arttığı, DYY girişi } \\
\text { arttıkça ise ihracatın } \\
\text { arttığı bulunmuştur. }\end{array}$ \\
\hline $\begin{array}{l}\text { Temiz ve } \\
\text { Gökmen (2009) }\end{array}$ & $\begin{array}{l}\text { 1991-2008 (aylık), } \\
\text { Türkiye }\end{array}$ & \begin{tabular}{|l|} 
Johansen \\
Eşbütünleşme Testi \\
ile Granger \\
Nedensellik \\
\end{tabular} & İhracat ve DYY & $\begin{array}{l}\text { DYY'lerin ihracat } \\
\text { artırıcı olmadığı } \\
\text { görülmektedir. }\end{array}$ \\
\hline
\end{tabular}




\begin{tabular}{|c|c|c|c|c|}
\hline $\begin{array}{l}\text { Bozdalıoğlu } \\
(2010)\end{array}$ & $\begin{array}{l}1992 \text { Ocak-2009 } \\
\text { Temmuz (aylık), } \\
\text { Türkiye }\end{array}$ & $\begin{array}{l}\text { Granger Nedensellik } \\
\text { ve Var }\end{array}$ & $\begin{array}{l}\text { İhracat, DYY, Dışa Açıklık } \\
\text { Oranı (İhracat/Gsmh), Hazine } \\
\text { Faiz Oranı, Reel Efektif } \\
\text { Döviz Kuru, Kriz Kukla } \\
\text { Değişkeni, Toptan Eşya Fiyat } \\
\text { Endeksi ve Sanayi Üretim } \\
\text { Endeksi }\end{array}$ & $\begin{array}{l}\text { DYY, ihracat } \\
\text { performansı üzerinde } \\
\text { olumlu bir etkiye } \\
\text { sahiptir. }\end{array}$ \\
\hline $\begin{array}{l}\text { Y1lmazer } \\
(2010)\end{array}$ & $\begin{array}{l}\text { 1991 Q1- 2007 Q3 } \\
\text { (çeyreklik), } \\
\text { Türkiye }\end{array}$ & Granger Nedensellik & $\begin{array}{l}\text { Gayri Safi Yurt İçi Hâsıla } \\
\text { (GSYİH), İthalat, DYY ve } \\
\text { İhracat }\end{array}$ & $\begin{array}{l}\text { DYY ile ihracat } \\
\text { arasında bir nedensellik } \\
\text { olmadığı bulunmuştur. }\end{array}$ \\
\hline $\begin{array}{l}\text { Delice ve Birol } \\
(2011)\end{array}$ & $\begin{array}{l}\text { 1992 Q1-2011 Q1, } \\
1992 \text { Q1-2001 Q4 } \\
\text { ve 2002 Q1-2011 } \\
\text { Q1 (çeyreklik), } \\
\text { Türkiye }\end{array}$ & $\begin{array}{l}\text { Sinır testi ve ARDL } \\
\text { modeli }\end{array}$ & İhracat, İthalat ve DYY & $\begin{array}{l}\text { Sadece 2002Q1-2011Q1 } \\
\text { döneminde ihracat ile } \\
\text { DYY arasında } \\
\text { eşbütünleşme ilişkisi } \\
\text { bulunmuştur. }\end{array}$ \\
\hline $\begin{array}{l}\text { Göçer vd. } \\
(2012)\end{array}$ & $\begin{array}{l}\text { 2000-2010 (yıllık), } \\
\text { Türkiye }\end{array}$ & $\begin{array}{l}\text { Sınır Testi Analizi, } \\
\text { Sınır Testi } \\
\text { Yaklaşımına Dayalı } \\
\text { ARDL, Granger } \\
\text { Nedensellik Testi, } \\
\text { Engle Granger ve } \\
\text { Johansen } \\
\text { Eşbütünleşme }\end{array}$ & İhracat ve DYY & $\begin{array}{l}\text { DYY'deki \%10'luk bir } \\
\text { artış, ihracatı \%1,4 } \\
\text { arttırmaktadır. }\end{array}$ \\
\hline Bayar (2013) & $\begin{array}{l}\text { 1974-2011 (yıllık), } \\
\text { Türkiye }\end{array}$ & $\begin{array}{l}\text { Var ve Toda } \\
\text { Yamamoto } \\
\text { nedensellik }\end{array}$ & İhracat ve DYY & $\begin{array}{l}\text { DYY ihracatın nedeni } \\
\text { değildir bulunmuştur. }\end{array}$ \\
\hline Öğ̈̈t vd. (2014) & $\begin{array}{l}\text { 1992:Ocak- } \\
\text { 2014:Mayıs (aylık), } \\
\text { Türkiye }\end{array}$ & $\begin{array}{l}\text { Johansen } \\
\text { Eşbütünleşme Testi, } \\
\text { Varyans Ayrıştırması } \\
\text { ve Etki Tepki } \\
\text { Fonksiyonu }\end{array}$ & İhracat ve DYY & $\begin{array}{l}\text { DYY girişleri ihracatı } \\
\text { arttırmaktadır. }\end{array}$ \\
\hline Koç (2015) & $\begin{array}{l}\text { 2007-2014 (yılllı), } \\
\text { Türkiye }\end{array}$ & $\begin{array}{l}\text { Toda-Yamamoto } \\
\text { Nedensellik }\end{array}$ & İhracat ve DYY & \begin{tabular}{|l} 
DYY'den ihracata \\
doğru nedensellik \\
ilişkisi bulunduğu \\
sonucuna ulaşılmıştır.
\end{tabular} \\
\hline Tapşsin (2016) & $\begin{array}{l}\text { 1974-2011(yıllık), } \\
\text { Türkiye }\end{array}$ & Granger nedensellik & DYY, Büyüme ve ihracat & $\begin{array}{l}\text { DYY girişleri ihracatı } \\
\text { arttırmaktadır. }\end{array}$ \\
\hline $\begin{array}{l}\text { Özbostanc1 } \\
(2016)\end{array}$ & $\begin{array}{l}\text { 1995-2014 (y1llık), } \\
\text { BRIC (Brezilya, } \\
\text { Rusya } \\
\text { Federasyonu, } \\
\text { Hindistan ve Çin) } \\
\text { Ülkeleri ile Türkiye }\end{array}$ & $\begin{array}{l}\text { Panel pedroni } \\
\text { Eşbütünleşme testi, } \\
\text { Sabit etkiler ve } \\
\text { Granger Nedensellik }\end{array}$ & İhracat ve DYY & $\begin{array}{l}\text { Türkiye'de DYY } \\
\text { girişlerinin ihracat } \\
\text { üzerinde etkisinin } \\
\text { olmadığı bulunmuştur. }\end{array}$ \\
\hline $\begin{array}{l}\text { Terzi ve Pata } \\
(2017)\end{array}$ & $\begin{array}{l}\text { 1982-2011 (yılllı), } \\
\text { Türkiye }\end{array}$ & $\begin{array}{l}\text { Varyans Ayrıştırma, } \\
\text { Etki-Tepki ve } \\
\text { Sims, Hsiao'nun } \\
\text { Granger, Toda- } \\
\text { Yamamoto Granger } \\
\text { Nedensellik } \\
\text { Analizleri } \\
\end{array}$ & $\begin{array}{l}\text { DYY, İthalat-İhracat ve Diş } \\
\text { Ticaret (İthalat+İhracat) }\end{array}$ & \begin{tabular}{|l} 
İhracattan DYY \\
girişlerine doğru tek \\
taraflı nedensellik \\
ilişkisi bulunmuştur.
\end{tabular} \\
\hline $\begin{array}{l}\text { Acaravc1 ve } \\
\text { Akyol (2017) }\end{array}$ & $\begin{array}{l}\text { 1998Q1-2015Q3 } \\
\text { (çeyreklik), } \\
\text { Türkiye }\end{array}$ & $\begin{array}{l}\text { Granger Nedensellik } \\
\text { ve Johansen } \\
\text { Eşbütünleşme Testi }\end{array}$ & $\begin{array}{l}\text { Dişa Açıklık Oranı } \\
\text { (İhracat+İthalat/GSYİH) } \\
\text { İthalat, İhracat ve DYY }\end{array}$ & $\begin{array}{l}\text { DYY ve ihracat } \\
\text { arasında nedensellik } \\
\text { ilişkisi tespit } \\
\text { edilememiştir. }\end{array}$ \\
\hline Gökçe (2018) & $\begin{array}{l}\text { 1990-2016 (yıllık), } \\
\text { BRIC ülkeleri ve } \\
\text { Türkiye }\end{array}$ & $\begin{array}{l}\text { Kao Eşbütünleşme } \\
\text { ve Panel AMG } \\
\text { Tahmincisi }\end{array}$ & $\begin{array}{l}\text { İhracat, Reel Efektif Kur, } \\
\text { Stok Olarak DYY ve Kriz } \\
\text { Kukla Değişkeni }\end{array}$ & $\begin{array}{l}\text { Türkiye'de DYY stoku } \\
\text { arttıkça ihracatın } \\
\text { azaldığı tespit } \\
\text { edilmiştir. }\end{array}$ \\
\hline
\end{tabular}




\begin{tabular}{|c|c|c|c|c|}
\hline Akman (2019) & $\begin{array}{l}\text { Ocak 2005-Ağustos } \\
2018 \text { (aylık), } \\
\text { Türkiye }\end{array}$ & ARDL Sınır Testi & $\begin{array}{l}\text { İhracat, DYY, Üretici Fiyat } \\
\text { Endeksi, Ticari Kredi Faiz } \\
\text { Oranı, Sanayi Üretim Endeksi } \\
\text { ve Reel Döviz Kuru }\end{array}$ & $\begin{array}{l}\text { DYY girişindeki } \\
\text { \%100'lük bir artış, } \\
\text { ihracatı \%39 } \\
\text { arttırmaktadır. }\end{array}$ \\
\hline $\begin{array}{l}\text { Canpolat } \\
(2019)\end{array}$ & $\begin{array}{l}\text { 2005-2017 (y1llık), } \\
\text { BRICS ve Türkiye }\end{array}$ & $\begin{array}{l}\text { Basit Doğrusal } \\
\text { Regresyon }\end{array}$ & İhracat ve DYY & $\begin{array}{l}\text { DYY girişlerinin } \\
\text { ihracatı arttırmadığ } \\
\text { bulunmuștur. }\end{array}$ \\
\hline \begin{tabular}{|l} 
Kastratović \\
$(2020)$
\end{tabular} & $\begin{array}{l}\text { 1960-2016 (y1llik), } \\
60 \text { Gelişmiş Ülke } \\
\text { ve } 184 \text { Gelişmekte } \\
\text { Olan Ekonomi }\end{array}$ & Meta Veri Analizi & $\begin{array}{l}\text { İhracat, Stok DYY, Brüt } \\
\text { Yatırım, Ev Sahibi Ülke } \\
\text { Açıkığı, Döviz Kuru, Dış } \\
\text { Talep, Çok Uluslu Şirketlerin } \\
\text { Faaliyet Göstergeleri, İhracat } \\
\text { Fiyatları ve İş Ortamı, Altyapı }\end{array}$ & $\begin{array}{l}\text { Türkiye'de DYY } \\
\text { girişleri ihracatı } \\
\text { azaltmaktadır. }\end{array}$ \\
\hline
\end{tabular}

\section{DOĞRUDAN YABANCI YATIRIM GİRIŞI VE IHRACAT ILIŞKİSİ: TEORÍK ÇERÇEVE}

Doğrudan yabancı yatırım (DYY) girişlerinin ev sahibi ülkenin ihracatı üzerindeki etkisi iki biçimde gerçekleşmektedir. $\mathrm{Bu}$ etkenlerden ilki, çok uluslu şirketlerin (ÇUŞ) yurt dişı iştiraklerinin yaptıkları ihracat olarak ifade edilen doğrudan etkidir. Bu etkenlerden diğeri ise, DYY'nin yerli şirketlerin ihracatı üzerindeki etkisi olarak ifade edilen dolaylı etkidir (Zhang, 2005: 4).

Yeni dış ticaret teorisi DYY girişlerinin ev sahibi ülke ihracatı üzerindeki doğrudan etkisinin doğrudan yabanc1 yatırım türüne bağlı olduğunu sürmektedir. Bu yaklaşıma göre doğrudan yabancı yatırım, yatay, dikey ve ihracat platformu biçiminde ayrılmaktadır. Yatay yatırımlar, piyasa arayan yatırımlardır ve bu yatırımların iç piyasayı hedeflemesinden kaynaklı olarak ihracatı etkilemesi beklenmemektedir. Dikey yatırımlar, kaynak arayan yatırımlar olarak da ifade edilmektedir. Dikey yatırımlar, şirketlerin ana merkezi ve iştirakleri arasında ara malların ya da nihai malların ticaret yaratmasından kaynaklı olarak ev sahibi ülkenin ihracatını arttırması beklenmektedir (Kastratović, 2020: 3144-3146). İhracat platformu DYY, firmaların yatırım yaptıkları ülkenin üretiminin önemli bir bölümünü ev sahibi ülkelere satmak yerine üçüncü ülkelere (üçüncü ülke ihracat platformu) ya da üçüncü ülke ve kaynak ülkeye (küresel ihracat platformu) ihraç etmesini açıklamaktadır. İhracat platformu DYY, hem dikey (kaynak arayış1 amaçlı) hem de yatay (pazar arayışı amaçlı) DYY'nin bileşenlerine sahiptir (Ekholm vd., 2003a: 2). İhracat platformu DYY, şirketlerin yurt dışına yatırımlarında serbest ticaret anlaşmaları, büyük pazarlara yakınlık ve üretim maliyetlerinin bir bütün olarak ne derece önemli olduğunu vurgulamaktadır. Bu bağlamda ihracat platformu DYY, ev sahibi ülke için ihracat artırıcı etkiler oluşturmaktadır (Ekholm vd., 2003b: 26).

Doğrudan yatırım ev sahibi ülkenin yerel firmalarının ihracatını çeşitli kanallarla etkilemektedir. Bunlar (Zhang ve Song, 2000: 389-390; Kneller ve Pisu, 2005: 2-3);

- Gözlem ve taklit: Yerel şirketler yabancı iştiraklerin ihracat faaliyetlerini ya da üretim, yeni teknoloji, yönetim ve pazarlama teknikleri gibi ihracatla doğrudan ilişkisi olmayan bilgileri gözlem ve taklit ederek ihracatlarını artırabilmektedir.

- Emeğin devri: ÇUŞ’lar işçilerini ihracat konusunda bilgilendirmekte ve eğer ÇUŞ'ların iştirakinde çalışan işçiler yerli şirketlerde çalışırsa veya kendi firmasını oluşturursa bu bilgiler yerli şirketlere aktarılabilmektedir.

- Rekabet etkisi: ÇUŞ'ların yerel piyasaya girişi yerel şirketleri pazar paylarını korumak için yeniliğe yönelik ar-ge çalışmalarına, gözlem ve taklit yapmaya ve kaynakları daha verimli 
kullanmaya zorlamaktadır. Böylece doğrudan yatırım, yerel firmalara yeni teknolojilerin yayılmasını sağlayarak verimliliklerini yükseltebilmektedir.

- İhracat bilgi dışsalıkları: Yerel firmalar yabancı firmalardan dış piyasalar hakkında bilgi edinebilmektedir. Bununla birlikte, ev sahibi ülkedeki iştirakler, yabancı pazarlara erişimi sağlayacak gerekli alt yapıların iyileşmesine yardımcı olarak ve kendi oluşturdukları finansal hizmetler, iletişim ve taşıma alt yapısını yerel şirketlere kullandırarak yerel firmaların ihracatlarının artmasını sağlamaktadır.

- Bağlantılar: Doğrudan yatırım, girdiği ülkede girdiler talep ederek (geri bağlantı) yerel tedarikçi firmaların oluşumunu ve mevcut yerel firmaların ölçek ekonomilerinin faydalarından yararlanmalarını sağlamaktadır. Ayrıca yerel tedarikçilerin kaliteli ürün, zamanında teslimat ve düşük defo gibi standartlara uymasını sağlayabilmektedir. Bununla birlikte, ÇUŞ’lar ürettiği ucuz, kaliteli ve yeni girdileri işleyecek firmalara (ileri bağlantı) da aynı etkileri sağlamaktadır. - Lobicilik: ÇUŞ'lar ülkelerinde ev sahibi ekonomiden gerçekleştirilecek ithalata kısıtlamaların kaldırılması için lobicilik faaliyetleri yaparak da yerli şirketlerin ihracatını arttırabilmektedir.

Hem Barrios vd. (2005) hem de Kneller ve Pisu (2004, 2005)'nun çalışmalarında ihracata yönelik yabancı iştiraklerin iç pazara yönelik yabancı iştiraklere kıyasla dolaylı etkilerin asıl kaynağı olduğu bulunmuştur. Bu nedenle dikey ve ihracat platformu doğrudan yabanc1 yatırımların ihracat üzerinde olumlu dolaylı etkilerinin bulunması da beklenmektedir. Bununla birlikte yatay yatırımların (iç pazar amaçlı yatırımlar) da bu nedenlerle dolaylı etkilerinin de bulunmaması beklenmektedir. Fakat DYY'nin ihracat üzerindeki etkisini -iç piyasa ya da ihracat amaçlı girmesinin haricinde- belirleyen olumsuz ve olumlu çok sayıda etken (teknoloji düzeyi, beşeri sermaye, hükümet politikaları gibi) vardır.

Doğrudan yabancı yatırım girişlerinin ev sahibi ülkenin ihracatı üzerindeki etkisi teorik olarak uçan kazlar modeli, ürünün yaşam evreleri modeli ve yeni büyüme teorileri ile açıklanmaktadır. $\mathrm{Bu}$ üç modelde de yabancı yatırım, ev sahibi ülkenin ihracatını doğrudan ve dolaylı olarak pozitif etkilemektedir. Ancak uçan kazlar ve ürünün yaşam evreleri modellerinde doğrudan etkilere yönelik bir vurgu; yeni büyüme modellerinde ise dolaylı etkilere yönelik bir ağırlık mevcuttur. Uçan kazlar modelinde, doğrudan yatırım üretim maliyetini (temelde emek) düşürecek faktör donatımına sahip ülkeye tahsis edilmektedir. Bu teoride, DYY'nin yeri, bir ülkenin sanayileşmesine bağlı olarak zamanla değişmektedir. Ürünü üreten ülke DYY ve taklit yoluyla zaman içerisinde değişmekte ve ihracatında ön planda olmaktadır. Modele göre, Japon tipi yatırımlar küresel ihracat platformuna girmektedir. Bu yaklaşımda, DYY'nin ihracat yayılmalarında bağlantılar kanalı ve gözlem/taklit etkisi vurgulanmaktadır (Njong ve Raymond, 2011: 187).

Ürünün yaşam evreleri teoremi yenilikleri temel almakta ve uçan kazlar modeline benzer biçimde ürünü üreten ülkenin DYY ve taklit yoluyla zaman içerisinde değiştiğini vurgulamaktadır. Söz konusu teoriye göre, her ürün üç aşamadan oluşan bir ürün yaşam evresine sahiptir. Bunlar, yeni, olgunlaşmış ve standartlaşmış ürün aşamalarıdır. Bu teoride, olgunlaşmış ürün aşamasının başlarında yatay doğrudan yabancı yatırım gerçekleştirilmektedir. Vernon (1966)'a göre bu aşamanın sonlarına doğru, emek maliyeti farkından dolayı Amerikan ÇUŞ'larının iştirakleri ana ülkeden gerçekleşen ihracatın yerini almakta ve hem ana ülkeye hem de üçüncü ülkelere ihracat gerçekleştirerek ev sahibi ekonominin ihracatını arttırmaktadır. $\mathrm{Bu}$ husus, küresel ihracat platformu DYY'i içermektedir. Standartlaşmış ürün aşamasında yenilikçi şirket dâhil olmak üzere tüm şirketler ucuz emekten faydalanmak için gelişmekte olan 
ekonomilere yatırım yapmaktadır. Bu süreçte zaman içerisinde ürün tüm dünyaya gelişmekte olan ekonomilerden ihraç edilmektedir. Bu aşamada da küresel ihracat platformu DYY söz konusudur. Bu yaklaşımda, DYY'nin ihracat yayılmalarında sadece gözlem/taklit etkisi ön plana çıkmaktadır.

Yeni büyüme teorilerinde (içsel büyüme modelleri), yabancı yatırımlar yerli şirketlerin yatırımlarını ve teknolojik gelişimini canlandıran önemli bir olgudur. Bu teorilerde dişsallıklar ve beşeri sermayenin mevcudu fiziksel sermayenin marjinal verimliliğinin azalmamasını sağlamakta ve artan verimlere neden olarak ekonomik büyümeyi ve ihracatı yükseltmektedir (Nair-Reichert ve Weinhold, 2001: 154). Yeni büyüme teorilerinde, DYY'nin ihracat yayılmalarında bağlantılar, gözlem/taklit ve rekabet kanalı kapsamlı bir şekilde vurgulanmaktadır.

Türkiye'de, 2006-2019 döneminde yabancı yatırımların, \%25'i finans sektörüne, \%23'ü gayrimenkul satın alımlarına, \%9,2'si enerjiye, \%5,3'ü ticarete ve \%4,7'si bilgi ve iletişim teknolojilerine gelmiştir. Ayrıca, \%4,6'sı gıda sektörüne, \%3,8'i ulaştırma ve depolamaya, \%3'ü kimya sektörüne, \%2,7'si inşaata, \%2,2'si ana metal sektörüne (özellikle demir-çelik), $\% 2$ 'si elektronik ürünlere, \%1'i tekstile ve \%0,7'si ulaşım araçları imalatına gelmiştir (TCMB, 17.09.2021).

Gayrimenkul alımı ve inşaat sanayisine giren yatırım yabancı yatırım girişlerinin yaklaşık \%26'sını meydana getirmektedir. $\mathrm{Bu}$ yatırımlar inşaat sanayisindeki yerli şirketlerin verimliliğini yükseltmekte, yeni teknolojilere erişmesini sağlamakta veya erişmesini zorlamaktadır. Bununla beraber geri ve ileri bağlantılarla özellikle demir-çelik sektörü olmak üzere birçok inşaat malzemeleri sektörünü ve özellikle turizm olmak üzere çok sayıda sektörü canlandırmaktadır. Tüm bunlar yerli şirketlerin gelişip ihracat yapmasını sağlamaktadır. Türk inşaat sektörü mal ihracatına senede yirmi milyar dolara yakın katkı vermektedir (İMSAD, 2019: 10; Özdemir, 2018: 50-51). Aynı zamanda Türkiye, dünya demir-çelik ihracatında da üst siralarda yer almaktadır (WTO, 2019: 29-40).

Türkiye ekonomisi ulaşım araçlarına (ana sanayi) yönelik yabancı yatırım amacıyla istenilen payı elde edememesine rağmen otomotiv ürünleri (ana ve yan sanayi) ihracatında çok önemli bir ülkedir. Ülke, özellikle gümrük birliği anlaşması içerisinde yer alması, coğrafi konumu, ucuz ve nitelikli iş gücü ve güçlü lojistik ağı ile otomotiv ana sanayisinde ihracata yönelik yabancı yatırım çekmektedir. Bununla beraber otomotive gelen yabancı yatırım, demir-çelik, elektronik araçlar, makine, tekstil, kimya gibi alt sanayilerin gelişmesini sağlamaktadır (Kalkınma Bakanlığı, 2018a: 45). Tüm bu faktörler, otomotiv ana sanayisine giren az bir yabancı yatırımın bile yan sanayide olan diğer sektörlerdeki yerli şirketlerin gelişimini ve ihracatlarının artmasına yardımcı olmaktadır. Bununla birlikte Türkiye, lojistik sektöründe de ciddi düzeyde yabancı yatırım çekmektedir. Lojistik sektörü, diğer sektörlerdeki yerli şirketlerin gelişmesini sağlayarak ihracatını yükseltmektedir (Kalkınma Bakanlığı, 2018b: 61). Son olarak, Türkiye son yıllarda kimya sanayisine de ciddi seviyede yabancı yatırım çekmektedir. Bu husus hem kimya sektörünün hem de bağlantılar yoluyla diğer sektörlerin ihracatının artmasına yardımcı olmaktadır (Kalkınma Bakanlığı, 2018a: 34-45). 


\section{TÜRKIYE'DE DOĞRUDAN YABANCI YATIRIMLARIN BENZER EKONOMILERLE KARŞILAŞTIRMALI SEYRİ}

Doğrudan yabancı yatırım düzenlemeleri kısıtlayıcı endeksi, OECD tarafından aralarında Türkiye'nin de bulunduğu 84 ülke ve 9 sektörü de kapsayacak şekilde oluşturulmuştur. Endeksin oluşmasında; yabancı sermaye kısıtlamaları, ayrımcı takip etme ve onaylama mekanizmaları, yabancı işçi kısıtlamaları ve operasyonel kısıtlamalar olmak üzere dört ana bileşen söz konusudur. Endeks 0 tam serbest, 1 tam kısıtlayıcı olmak üzere 1 ila 0 arasında değişmektedir (OECD, 14.09.2021).

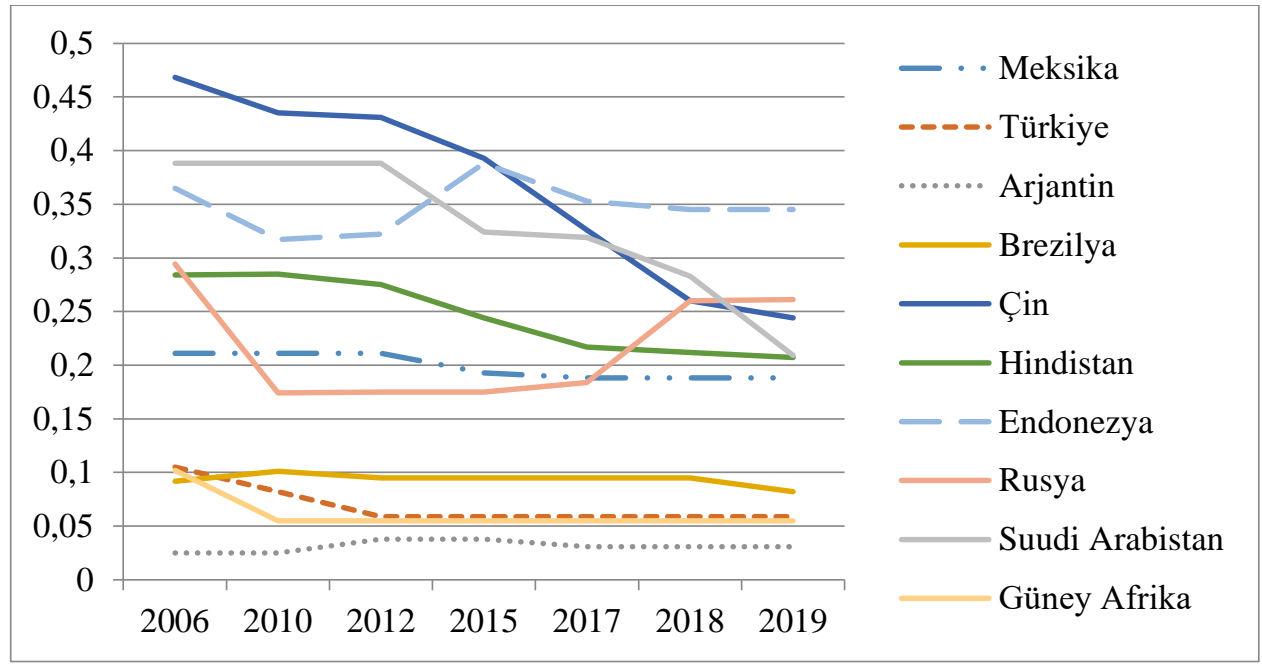

Şekil 3. G-20 Üyesi Gelişmekte Olan Ülkelerinde Doğrudan Yabancı Yatırım Düzenlemeleri Kısıtlayıcı Endeksi (2006-2019)

Kaynak: OECD, 14.09.2021.

Şekil 3'te aralarında Türkiye'nin bulunduğu G-20 üyesi gelişmekte olan ülkelerde doğrudan yabancı yatırım düzenlemeleri kısıtlayıcı endeksinin gelişimi seçilmiş yıllar için gösterilmektedir. Şekil 3'ten de anlaşıldığı üzere, Türkiye G-20'nin gelişmekte olan ülkeler arasında doğrudan yabancı yatırım düzenlemeleri açısından en serbest ekonomiler arasındadır. Ayrıca Türkiye 2006-2019 yılları arasında G-20'nin gelişmekte olan ülkeler arasında doğrudan yabancı yatırım düzenlemelerine yönelik en fazla serbestleşen ekonomiler arasında ilk siralardadir. 


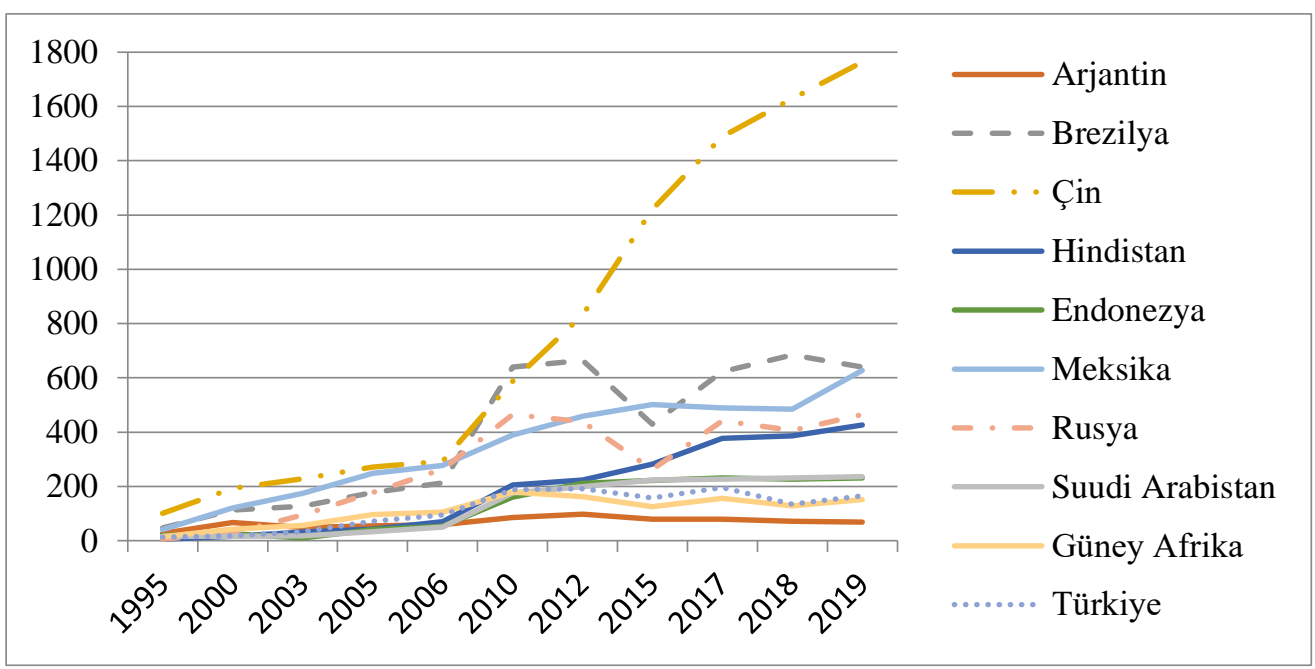

Şekil 4. G-20 Üyesi Gelişmekte Olan Ülkelerinde Doğrudan Yabancı Yatırım Stoku (Milyar Dolar, 1995-2019)

Kaynak: UNCTAD, 17.09.2021.

Şekil 4'te G-20 üyesi gelişmekte olan ekonomilerde doğrudan yabancı yatırım stokunun gelişimi seçilmiş yıllar için gösterilmektedir. Şekil 4'te görüldügü üzere ise Türkiye ekonomisinde stok olarak DYY girişleri G-20 üyesi diğer gelişmekte olan ülkelere göre sürekli olarak zayıftır. Bu bağlamda, Türkiye doğrudan yabancı yatırım düzenlemeleri açısından bu ülkeler arasında en serbest ekonomiler arasında olmasına rağmen; DYY girişinde potansiyeline erişememiştir. Bu durumun nedenleri arasında, ülkenin 2000'lerin başına kadar çok sayıda ekonomik krizler yaşaması, uzun yıllar siyasi istikrarsızlık, bozuk makro ekonomik denge ve zayıf mülkiyet haklarına sahip olması sayılabilmektedir (Gür, 2014: 68). Aynı zamanda son yıllarda siyasi ve toplumsal olaylar gibi ülkenin kendine özgü riskleri ve jeopolitik ve küresel ekonomik sorunlar gibi dışsal riskler de önemli rol oynamaktadır.

\section{EKONOMETRIK YÖNTEM}

$\mathrm{Bu}$ araştırmada beş aşamalı bir ekonometrik analiz süreci takip edilecektir. İlk aşamada önce geleneksel birim kök testleri arasında olan “Dickey-Fuller (1981)'nin oluşturduğu Genişletilmiş Dickey Fuller (ADF) birim kök testi” kullanılarak serilerin durağanlığ1 sınanacaktır. Bu testin $\mathrm{H}_{0}$ hipotezi değişkenin birim kök içerdiği biçimindedir. ADF birim kök testinde serilerin sabitli ve sabit ve trendli olup olmamasına göre analiz yapılmaktadır. Her iki testte de test istatistikleri MacKinnon kritik değerinden küçük olduğunda değişkenin birim kök içerdiği, büyük olduğunda ise değişkenin birim kök içermediği belirtilmektedir (Özcan, 2007: 144).

Ülkelerin ekonomik gelişimlerinde zaman içerisinde yaşadığı yapısal değişimleri dikkate almayarak analiz eden geleneksel birim kök testlerinin bu eksiklikleri yapısal kırılmalı birim kök testleriyle yardımıyla giderilmeye çalışılmıştır. Bu bağlamda yanlış çıkarımlarda bulunma hatası söz konusu olmamaktadır (Perron, 1989). Bu sorunun çözümü için ani yapısal kırılmaya izin veren ve tek kırılmayı modele dâhil eden "Zivot ve Andrews (ZA) (1992) yapısal kırılmalı 
birim kök testi” kullanılacaktır. Bu testin de $\mathrm{H}_{0}$ hipotezi değişkenin birim kök içerdiği şeklindedir.

"ZA yapısal birim kök testinde, kırılma noktasını bulmak için, her olası kırılma tarihi için farklı bir gölge değişkenden yararlanılarak $t=2, \ldots,(T-1)$ için En Küçük Kareler (EKK) yöntemiyle ardışık olarak (T-2) sayıda regresyon oluşturulur ve $\mathrm{y}_{\mathrm{t}-1}$ değişkeninin katsayısı olan $\alpha$ 'nın en küçük $t$ istatistiğine sahip olduğu modeldeki tarih, uygun kırılma noktası olarak seçilir" (Y1lanc1, 2009: 328).

Kırılma tarihi tespit edildikten sonra $\alpha$ 'nın hesaplanan $t$ istatistiği mutlak değer olarak ZA kritik değerinden büyük olduğu taktirde yapısal kırılma olmadan birim kökün mevcudunu belirten $\mathrm{H}_{0}$ hipotezi reddedilmektedir. Hesaplanan $t$ istatistiği ZA kritik değerinden mutlak değerce küçük olması durumunda ise trend fonksiyonunda oluşan bir yapısal kırılmayla beraber değişkenin trend durağanlığını ifade eden alternatif hipotez reddedilmektedir (Yılanc1, 2009: 328).

Sonraki aşamada, eşbütünleşme testini uygulamak amacıyla optimal gecikme sayısı belirlenecektir. Uygun gecikme uzunluğu tespit etmek amacıyla birtakım yöntemler bulunmaktadır. Bunlar arasında, "Ardışık modifiye edilmiş LR test istatistiği (LR), Son Tahmin Hatası kriteri (Final prediction error: FPE), Akaike bilgi kriteri (Akaike Information Criterion: AIC), Schwarz bilgi kriteri (Schwarz information criterion: SC) ve Hann Quin bilgi kriteri (Hann Quin information criterion: HQ) en fazla kullanılan kriterler arasında yer almaktadır" (Peker, 2009: 169).

Üçüncü aşamada, değişkenler arasındaki uzun dönemli ilişki "Johansen (1991) eşbütünleşme testi" ile sınanacaktır. Bu testte seriler arasındaki eş bütünleşme ilişkisinin varlığına karar vermek için maksimum öz değer ve iz istatistiklerinden biri ya da ikisi kritik değerlerle karşılaştırılmaktadır. Testin $\mathrm{H}_{0}$ hipotezi “eşbütünleşme yoktur" şeklindedir. Test istatistikleri kritik değerlerden büyük olması durumunda $\mathrm{H}_{0}$ hipotezi reddedilerek eşbütünleşmenin varlığ1 bulunmaktadır (Demirgil, 2019: 179). Ardından değişkenlerin uzun dönem katsayıları bulunacaktır. $\mathrm{Bu}$ süreçte her bir değişken için ulaşılan $\mathrm{t}$ istatistiklerinin $\mathrm{t}$ tablosu kritik değerlerinden mutlak olarak büyük olduğunda anlamlı olduğu belirtilmektedir. Eşbütünleşme tahmincisi testinin $\mathrm{H}_{0}$ hipotezi, katsayıların anlamsız olduğu şeklinde kurulmaktadır. Test sonucunda $\mathrm{t}$ istatistiği kritik değerden mutlak olarak büyük olduğunda $\mathrm{H}_{0}$ hipotezi reddedilmektedir.

Dördüncü aşamada, değişkenler arasındaki uzun dönem denge ile kısa dönem dinamikler arasındaki ilişkiyi tespit etmek amacıyla "Vektör Hata Düzeltme Modeli" kullanılacaktır. Hata Düzeltme Modeli, kısa dönemde ortaya çıkan sapmaların ne kadar süre ile düzeltildiğini belirtmektedir. Hata düzeltme teriminin işaretinin negatif ve istatistiksel olarak anlamlı olması beklenmektedir. $\mathrm{Bu}$ durum, değişkenlerin uzun dönem denge değerine doğru hareketinin olacağını ifade etmektedir. Katsayının büyüklüğü, uzun dönem denge değerine yakınlaşma hızını göstermektedir. Hata düzeltme teriminin işaretinin pozitif ve istatistiksel olarak anlamlı olması ise, uzun dönem denge değerinden uzaklaşmayı göstermektedir (Kocabıyık, 2016: 4749).

Son aşamada, değişkenler arasındaki ilişkinin yönünü doğrulamak amacıyla "Granger (1969) nedensellik testi" uygulanacaktır. Granger nedensellik testinde seriler arasındaki nedenselliğe karar vermek için, bağımsız değişkenin gecikmeli değerlerinin katsayılarının belirli bir anlamlılık seviyesinde sıfıra eşit olup olmadığı sınanmaktadır. Testin $\mathrm{H}_{0}$ hipotezi "nedensellik 
yoktur" şeklindedir. Kat sayılar sıfırdan farklı olduğundan bağımsız değişkenin bağımlı değişkenin nedeni olduğu bulunmaktadır (Göçer vd., 2012: 29-30).

\section{VERI SETİ VE EKONOMETRIK TAHMIN SONUÇLARI}

\subsection{Veri Seti}

$\mathrm{Bu}$ araştırmada Türkiye'de doğrudan yabancı yatırım girişlerinin uzun dönemde ihracat üzerindeki etkisi 1980-2019 dönemi verileri çerçevesinde eşbütünleşme ve nedensellik analizleri ile incelenmiştir.

Araştırmada uygulanan modelin kurulmasında, Majeed ve Ahmad (2007) ve Selimi vd. (2016)'nun çalışmaları temel alınmıştır. Çalışmada, modelde ihracatın GSYİH'ye oranı, stok olarak doğrudan yabancı yatırım girişlerinin GSYİH'ye oranı ve kontrol değişkeni olarak da reel efektif döviz kuru endeksi kullanılmaktadır. İhracatın GSYİH’ye oranı Dünya Bankası tarafından yayınlanan Dünya Kalkınma Göstergelerinden elde edilirken, doğudan yabanc1 yatırımların GSYİH'ye oranı ve reel efektif döviz kuru verisi ise sırasıyla Birleşmiş Milletler Ticaret ve Kalkınma Konferansı ve Bruegel veri tabanlarından elde edilmiştir (Tablo 2). Ayrıca çalışmada E-views 10.0 ve Gauss 21.0 ekonometrik paket programları kullanılmıştır.

Tablo 2. Ampirik Analizde Kullanılan Değişsenler

\begin{tabular}{|l|l|l|}
\hline Simgesi & Açılklaması & Kaynă̆ $\mathbf{~}$ \\
\hline LíHRC & İhracat/GSYİH (\%) (Logaritmik) & Dünya Bankası, WDI \\
\hline LDYY & $\begin{array}{l}\text { Doğrudan yabancı yatırımlar Girişi /GSYİH (\%) } \\
\text { (Logaritmik) }\end{array}$ & $\begin{array}{l}\text { UNCTAD, } \\
\text { UNCTADSTAT }\end{array}$ \\
\hline LREK & $\begin{array}{l}\text { Reel Efektif Döviz Kuru Endeksi (2007=100) } \\
\text { (Logaritmik) }\end{array}$ & Bruegel \\
\hline
\end{tabular}

Araştırmada kullanılacak modeller, değişkenlerin logaritmik dönüşümleriyle Denklem 1'de gösterilmiştir:

$$
\operatorname{LIHRC}_{i t}=\beta_{0}+\beta_{l i} L D Y Y_{i t}+\beta_{2 i} L R E K_{i t}+\varepsilon_{i t}
$$

Çalışmada modelde beklenen sonuçlar şu şekildedir (Njong ve Raymond, 2011: 188):

- Doğrudan yabancı yatırım girişlerinin yukarıda açıklanan teorik çerçeveden hareketle ihracatı arttırdığ 1 ileri sürülmektedir. Dolayısıyla bu parametrenin $\beta_{1}>0$ beklenmektedir.

- Reel efektif döviz kurundaki artışlar*, ulusal paranın reel olarak değer kazanmasını ifade etmektedir. Reel efektif döviz kurundaki artışlar, yurt içinde üretilen malların değerini yurt dışında üretilen mallara kıyasla pahalılaştırmakta ve böylece ihracatı azaltmaktadır. Bundan dolayı çalışmada, bu parametrenin $\beta_{2}<0$ biçiminde olması beklenmektedir.

\subsection{Ekonometrik Tahmin Sonuçları}

Zaman serisi analizinde ilk önce her bir değişken birim kök testlerine tabi tutulacaktır Ardından optimal gecikme uzunluğu, eşbütünleşme testi ve katsayıların tahmini yapılacaktır.

\footnotetext{
* Reel Ef ektif Döviz Kuru $=\frac{\text { Yurt İçi Fiyat Endeksi }}{\text { Yurt Dışı Fiyat Endeksi }} x$ Nominal Efektif Döviz Kuru biçiminde hesaplanmaktadır (BRUEGEL, 2012: 2).
} 
Birim köke sahip zaman serileri ile gerçekleştirilen regresyon analizlerinde, oluşturulan modelde aslında ilişkisiz olan değişkenlere rağmen yüksek $R^{2}$ sonucu tespit edilebilmektedir. $\mathrm{Bu}$ durumda sahte regresyon problemi meydana gelmektedir (Ăğr vd., 2020: 61). Bu nedenle analiz edilecek modeldeki bir serinin durağanlığının incelenmesi oldukça önemlidir. "Bir seri, sabit aritmetik ortalama, sabit varyans ve sabit kovaryansa (kovaryanstaki değişmeler sadece gecikme mesafesine bağl1) sahipse durağandır şeklinde ifade edilmektedir” (Gujarati, 1999: 740).

Analizde önce serilerin durağan sürece sahip olup olmadıkları test edilecektir. Bu aşamada sıklıkla kullanılan geleneksel birim kök testi olan "Genişletilmiş Dickey Fuller (ADF)" yararlanılacaktır. LIHRC, LDYY ve LREK değişkenleri için ADF birim kök testinin bulguları Tablo 3'te verilmektedir.

Tablo 3. ADF Birim Kök Test Sonuçları

\begin{tabular}{|l|l|l|l|}
\hline & & \multicolumn{2}{|c|}{ ADF } \\
\hline & Model & Seviye & Birinci Fark \\
\hline \multirow{2}{*}{ LiHRC } & S & $-0,447$ & $-4,658^{* * * *}$ \\
\cline { 2 - 4 } & S\&T & $-3,307$ & $-4,555^{* * * *}$ \\
\hline \multirow{2}{*}{ LDYY } & S & $-0,472$ & $-10,681^{* * * *}$ \\
\cline { 2 - 4 } & S\&T & $-1,738$ & $-6,254^{* * * *}$ \\
\hline \multirow{2}{*}{ LREK } & S & $-1,672$ & $-7,288^{* * * *}$ \\
\cline { 2 - 4 } & S\&T & $-2,137$ & $-7,187^{* * *}$ \\
\hline
\end{tabular}

Not: S: Sabitli model. S\&T: Sabit ve trendli model,ST\&TR: Sabit Terimsiz ve Trendsiz Model. ADF testinde, optimum gecikme sayısı Akaike Bilgi Kriterine göre tespit edilmiş ve maksimum gecikme sayısı 4 olarak alınmıştır. ADF testinde kritik değerler sabitli model için -2,95 (\%5), sabit ve trendli model için $-3,55$ (\%5)'dir. * sembolü Ho hipotezinin $\% 5$ anlam düzeyinde reddedildiğini vermektedir.

ADF testinin $\mathrm{H}_{0}$ hipotezi birim kökün mevcudu varsayımına dayalıdır. ADF test istatistiği sonuçlarına göre ihracat, doğrudan yabancı yatırım girişi ve reel efektif kur endeksi düzeyde birim köke sahiptir. Fakat tüm seriler $\% 5$ anlam düzeyinde birinci farklarında durağandırlar. Böylece serilerin I (1) olduğunun sonucuna varılmaktadır. Bir diğer deyişle, geleneksel birim kök testlerinde seviyede birim kök sürecine sahip olan seriler, birinci dereceden farklarında durağan hale gelmektedir.

Yapısal kırılmalı birim kök testinin bulguları ise Tablo 4'te verilmektedir. Bu aşamada Zivot ve Andrews yapısal kırılmalı birim kök testi kullanılmaktadır.

Tablo 4. Zivot ve Andrews Birim Kök Testi Bulguları

\begin{tabular}{|c|c|c|c|c|c|}
\hline & & \multicolumn{4}{|c|}{ ZA (Ani Tek Kırılmalı, 1992) } \\
\hline & & \multicolumn{2}{|l|}{ Seviye } & \multicolumn{2}{|l|}{ Birinci Fark } \\
\hline Değişkenler & Model & $A D F$ Istatistiği & $\begin{array}{l}\text { Kırılma } \\
\text { Noktası }\end{array}$ & ADF Istatistiği & $\begin{array}{l}\text { Korılma } \\
\text { Noktast }\end{array}$ \\
\hline \multirow{2}{*}{ LİHRC } & $\mathrm{S}$ & $-4,366$ & 1988 & $-5,088^{* * * *}$ & 2014 \\
\hline & S\&T & $-4,312$ & 1999 & $-5,186^{* * *}$ & 1991 \\
\hline \multirow{2}{*}{ LDYY } & $\mathrm{S}$ & $-2,872$ & 1985 & $-10,889^{* * * *}$ & 1989 \\
\hline & S\&T & $-4,850$ & 1988 & $-11,109^{* * * *}$ & 2008 \\
\hline \multirow[b]{2}{*}{ LREK } & $S$ & $-3,355$ & 2015 & $-8,457^{* * *}$ & 1986 \\
\hline & S\&T & $-3,393$ & 2013 & $-8,530^{* * * *}$ & 2000 \\
\hline
\end{tabular}

Not. S: Sabitli model. S\&T: Sabit ve trendli model. Optimum gecikme sayısı Schwarz Bilgi Kriterine göre hesaplanıp, maksimum gecikme sayısı 4 olarak varsayılmıştır. Sabitli model için, \%5 anlamlılık seviyesinde ZA kritik değerleri: - 
4,8000; sabitli ve trendli model için $\% 5$ anlamlılık seviyesinde ZA kritik değerleri: $-5,0800$ biçimindedir. *** sembolü $\% 5$ 'te boş hipotezin reddedildiğini göstermektedir.

ZA yapısal kırılmalı birim kök testine göre ihracat, doğrudan yatırım girişi ve reel efektif kur değişkenleri düzeyde $\% 5$ anlamlılık seviyesinde birim kök sürece sahiptir. Bununla birlikte, tüm seriler birinci farklarında durağandırlar. ADF ve ZA yapısal kırılmalı birim kök testlerinin bulguları birbiri ile uyumlu olup, her iki birim kök testine göre üç seri de seviyede birim köke sahip olup birinci farklarında durağan hale gelmiştir. Yani, eşbütünleşme testini uygulamak için modellerde serilerin aynı dereceden durağan olma şartı sağlanmıştır (Ceylan ve Başer, 2014: 55).

Gecikme uzunluğu testine ait bulgular Tablo 5'te verilmektedir. Tablo 5'teki değerler dikkate alındığında; optimal gecikme uzunluğunun (otokorelasyon içermeyen model) 1 olduğu tespit edilmiştir. Çünkü Türkiye ekonomisi için kurulan modelde LR, FPE, AIC, SC ve HQ kriterleri $\% 5$ anlamlılık düzeyinde 1 gecikmede anlamlı sonuçlar sunmaktadır.

Tablo 5. Gecikme Uzunluğu Seçimi

\begin{tabular}{|l|l|l|l|l|l|l|}
\hline $\begin{array}{c}\text { Gecikme } \\
\text { Sayıs }\end{array}$ & LogL & LR & FPE & AIC & SC & HQ \\
\hline 0 & 99,841 & NA & $9,25 \mathrm{e}-07$ & $-5,380$ & $-5,248$ & $-5,333$ \\
\hline $\mathbf{1}$ & 160,915 & $108,576^{*}$ & $5,14 \mathrm{e}-08^{*}$ & $-8,273^{*}$ & $-7,745^{*}$ & $-8,088^{*}$ \\
\hline 2 & 169,118 & 13,216 & $5,44 \mathrm{e}-08$ & $-8,228$ & $-7,305$ & $-7,906$ \\
\hline 3 & 172,847 & 5,386 & $7,51 \mathrm{e}-08$ & $-7,935$ & $-6,616$ & $-7,475$ \\
\hline 4 & 183,571 & 13,703 & $7,23 \mathrm{e}-08$ & $-8,031$ & $-6,316$ & $-7,433$ \\
\hline
\end{tabular}

Not. * işareti kriter tarafından \%5 anlamlılık seviyesinde seçilen optimal gecikmeyi göstermektedir.

Uygun gecikme uzunluğunun belirlenmesinin ardından değişkenler arasındaki eşbütünleşme iliş̧isi (uzun dönemli ilişki) Johansen (1991) eşbütünleşme testi ile sınanmıştır. Johansen eşbütünleşme testi modeldeki tüm değişkenlerin düzeyde birim kök sürecine sahip olması ve farkı alındığında aynı dereceden durağan olması şartının gerçekleşmesi ile uygulanabilmektedir. Analizin başında uygulanan birim kök testlerinde tüm serilerin I (1) yani birinci dereceden durağan olduklarının tespitinden dolayı Johansen eşbütünleşme testi gerçekleştirilmiştir (Türkmen vd., 2018: 138).

Johansen eşbütünleşme testine ilişkin bulgular Tablo 6'da verilmiştir. Tablo 6'da gösterilen sonuçlar dikkate alındığında, Türkiye ekonomisi için seriler arasında eşbütünleşme ilişkisi bulunmadığını belirten $(\mathrm{r}=0) \mathrm{H}_{0}$ hipotezi iz istatistik değerlerinin kritik değerlerden büyük olması nedeniyle reddedilmektedir. Bundan hareketle ihracat, doğrudan yabancı yatırım girişi ve reel efektif kur endeksi değişkenleri arasında uzun dönemli iliş̧inin bulunduğu yani eşbütünleşme ilişkisinin olduğu tespit edilmiştir. Buna göre, bu değişkenler uzun dönemde birlikte hareket etme eğilimi içerisindedir.

Tablo 6. Johansen Eşbütünleşme Testi

\begin{tabular}{|c|c|c|c|}
\hline Hipotez & $\dot{I}_{z}$ Istatistiği & Kritik değer (\%5) & p-value \\
\hline $\mathrm{r}=0$ Yok $*$ & 43,735 & 42,415 & 0,0413 \\
\hline $\mathrm{r} \leq 1$ En az 1 & 18,474 & 25,872 & 0,3129 \\
\hline
\end{tabular}

Not. * sembolü Ho hipotezinin \%5 anlam düzeyinde reddedildiğini gösterir.

Türkiye ekonomisinde eşbütünleşme ilişkisi tespit edildikten sonra eşbütünleşme katsayılarına ilişkin bilgiler Tablo 7'de sunulmaktadır. 
Tablo 7. Eșbütünleșme Denklemi

\begin{tabular}{|c|c|c|c|c|c|}
\hline$\ddot{U} l k e$ & Değişkenler & LIHRC & $L D Y Y$ & LREK & C \\
\hline \multirow{4}{*}{ TÜRKIYYE } & Katsayı & 1,000 & -0.530 & 0.902 & -0.130 \\
\hline & Standart Hata & & 0.089 & 0.198 & \\
\hline & t İstatistiği & & -5.913 & 4.548 & \\
\hline & $\begin{array}{l}\text { Eşbütünleşme } \\
\text { Denklemi }\end{array}$ & \multicolumn{4}{|c|}{ LIHRC $=0,130+* 0,530$ LDYY-*0,902LREK } \\
\hline
\end{tabular}

Not. Eşbütünleşme denkleminde kritik değerler \%5 için 1,96'dır.

Tablo 7'deki sonuçlar göz önünde alındığında, Türkiye ekonomisi için, ihracat, doğrudan yabancı yatırım girişi ve reel efektif kur endeksi değişkenlerinin kat sayılarının istatistiksel olarak \%5 seviyesinde anlamlı ve beklenen işaretlerde olduğu görülmektedir. Bu bakımdan, Türkiye ekonomisi için doğrudan yabancı yatırım girişlerindeki \%1'lik bir artışın ihracatı $\% 0,530$ artırdığı ifade edilmektedir. Bununla birlikte ulaşılan bulgulara göre, Türkiye ekonomisinde reel efektif döviz kurundaki düşüşler ihracatı olumlu etkilemektedir.

Türkiye ekonomisinde eşbütünleşme ilişkisinin bulunması doğrultusunda, değişkenlerin kısa dönemdeki sapma eğilimlerini saptamak amaciyla Vektör Hata Düzeltme Modeli tahmin edilmiştir. Vektör Hata Düzeltme Modeline yönelik sonuçlar Tablo 8'de sunulmaktadır.

Tablo 8. Vektör Hata Düzeltme Modeli Tahmin Sonuçları

\begin{tabular}{|l|l|l|l|}
\hline & Katsayl & Standart Hata & $\boldsymbol{t}$ İstatistiğ \\
\hline $\mathrm{EC}_{\mathrm{t}-1}$ & $-0,714$ & 0,208 & $-3,431^{*}$ \\
\hline $\mathrm{D}($ LIHRC(-1)) & 0,181 & 0,190 & 0,948 \\
\hline $\mathrm{D}(\mathrm{LDYY}(-1))$ & $-0,156$ & 0,100 & $-1,553$ \\
\hline $\mathrm{D}(\mathrm{LREK}(-1))$ & 0,530 & 0,319 & 1,166 \\
\hline Sabit & 0,013 & 0,010 & 1,313 \\
\hline
\end{tabular}

Not. Vektör hata düzeltme modelinde kritik değerler \%5 için 1,96'dır.

Tablo 8'de gösterilen sonuçlar dikkate alındığında, hata düzeltme modelinin katsayısı -0,714 olarak tahmin edilmiş ve kat sayı \%5 düzeyinde anlamlı bulunmuştur. Bu katsayı, kısa dönemde ihracatta meydana gelecek bir sapmanın her yıl \%71,40'lık kısmı giderilerek uzun dönem dengesine ulaşabileceğini göstermektedir. Buna göre, bu yıl içerisinde yaşanacak bir sapma yaklaşık 1,4 yılda azalarak dengeye gelmektedir. Bununla birlikte katsayının işaretinin negatif olması Johansen eşbütünleşme testinde bulunan seriler arasında eşbütünleşmenin var olduğu yönündeki bulguyu desteklemektedir.

Son olarak, hem eşbütünleşme analizinin sonuçlarını doğrulamak hem de değişkenler arasındaki ilişkinin yönünü tespit etmek için Granger nedensellik testi gerçekleştirilmiştir. Bu teste yönelik sonuçlar Tablo 9'da verilmektedir.

Tablo 9. Granger Nedensellik Testi

\begin{tabular}{|c|c|c|}
\hline Slfir Hipotezi & $F \dot{I}$ Istatistiği & p-value \\
\hline LDYY, LİHRC'nin Granger nedeni değildir. & 7,071 & $0,011^{*}$ \\
\hline LİHRC, LDYY'nin Granger nedeni değildir. & 1,052 & 0,311 \\
\hline LREK, LİHRC'nin Granger nedeni değildir. & 7,358 & $0,010^{*}$ \\
\hline LIHRC, LREK'in Granger nedeni değildir. & 3,221 & 0,081 \\
\hline LREK, LDYY'nin Granger nedeni değildir. & 10,420 & $0,002^{*}$ \\
\hline LDYY, LREK'in Granger nedeni değildir. & 0,879 & 0,354 \\
\hline
\end{tabular}

Not. * sembolü Ho hipotezinin \%5 anlam düzeyinde reddedildiğini gösterir. 
Tablo 9 incelendiğinde, Türkiye ekonomisinde doğrudan yabancı yatırım girişinden ihracata tek yönlü bir nedensellik bulunmuştur. Aynı zamanda reel efektif kur endeksinden ihracata doğru da tek yönlü bir nedensellik ilişkisi tespit edilmiştir. Bu bulgular, Türkiye'de eşbütünleşme analizine paralel olarak uzun dönemde doğrudan yabancı yatırım girişlerindeki artışların ve reel efektif döviz kurundaki düşüşlerin ihracatı arttırdığını göstermektedir.

\section{SONUÇ}

$\mathrm{Bu}$ araştırmada, Türkiye ekonomisinde 1980-2019 döneminde doğrudan yabancı yatırım girişlerinin uzun dönemde ihracat üzerindeki etkisi eşbütünleşme ve nedensellik analizleri ile incelenmiştir. Bu amaçla modelde mal ihracatı/gayri safi yurt içi hâsıla (GSYİH), stok olarak doğrudan yabancı yatırım girişleri/GSYİH ve kontrol değişkeni olarak da reel efektif döviz kuru endeksi kullanılmıştır. Eşbütünleşme analizi sonucunda ulaşılan bulgular, Türkiye ekonomisinde doğrudan yatırım girişlerindeki \%1'lik bir artışın ihracatı \%0,53 artırdığı yönündedir. Ayrıca hata düzeltme modelinin negatif ve istatistiksel olarak anlamlı olması, seriler arasında eşbütünleşmenin var olduğu yönündeki bulguyu desteklemektedir. Dengeden uzaklaşma yaşandığında, sapmaların \%71,40'ının ilgili yıl sonu itibarıyla azalacağı ifade edilmektedir. Aynı zamanda nedensellik analizinden elde edilen bulgular, Türkiye'de doğrudan yabancı yatırımların ihracatı artırdığını desteklemektedir. Bulgular ilgili literatürde daha önce yapılan çalışmaların önemli bir kısmının (Altıntaş (2009); Bozdalığlu (2010); Delice ve Birol (2011); Göçer vd. (2012); Öğüt vd. (2014); Koç (2015); Tapşın (2016); Akman (2019)) sonuçlarıyla paralellik göstermektedir.

Sonuçlar, Türkiye ekonomisine gerçekleştirilen DYY'lerin genelde dikey (kaynak arayış1 amaçlı) ve ihracat platformu DYY biçiminde olduğunu ve ihracatı arttırdığını yansıtmaktadır. Türkiye, nitelikli ve ucuz iş gücü ve yabancı yatırımcılar için uygun vergi ve teşvik uygulamalarıyla ihracata yönelik olan dikey DYY çekmektedir. Bununla birlikte Türkiye'nin Avrupa, Orta Doğu ve Orta Asya'nın kesişim noktasındaki stratejik konumu, Avrupa Birliğiyle gümrük birliği içerisinde olması ve çok sayıda ülkeyle serbest ticaret anlaşmasına taraf olması da ihracat platformu DYY çekmesini sağlamaktadır. Türkiye'ye doğrudan yatırım girişlerinin bir kısmının otomotiv gibi montaj sanayi biçiminde yatırımlar olması, yabancı yatırımcıların yatırım yapma motivasyonlarının işgücü, ulaşım maliyetlerini ve ticari engelleri azaltarak büyük pazarlara ihracat yapmak üzerine oluşturdukları biçiminde ifade edilebilir (Doğanay ve Değer, 2017: 138). Aynı zamanda Türkiye gayrimenkul ve inşaat, lojistik sektörü ve kimya sanayi gibi sektörlerde önemli seviyede yatırım çekerken; bir yandan bu sektörlerin diğer yandan bağlantılar gibi kanallarla diğer sektörlerdeki yerli şirketlerin gelişimini sağlayarak ihracatını yükseltmektedir (TCMB, 17.09.2021). Bu bağlamda Türkiye ekonomisi için ulaşılan sonuçlar, ürünün yaşam evreleri teorisi, uçan kazlar modeli ve yeni büyüme teorileri çerçevesinde ortaya konulan DYY girişlerinin ihracatı artıracağı hipotezini savunan teorik çerçeveyi desteklemektedir.

Sonuç olarak elde edilen bulgular, Türkiye ekonomisinde ihracatın arttırabilmesi için DYY girişlerinin önemli bir rol oynadığını göstermektedir. Bu nedenle Türkiye'de, hükümetlerin daha fazla DYY çekmek ve DYY'nin ihracat üzerindeki etkinliğini yükseltmek için çeşitli politikalar uygulaması gerektiği belirtilebilir. Bu kapsamda ilk olarak, nitelikli iş gücünü, yurt içindeki rekabeti ve teknolojik düzeyi artırmaya yönelik politikalar uygulanmalıdır. Aynı zamanda, finansal sistem, kurumsal ve hukuksal çerçeve ve ekonomik entegrasyonların etkinliği geliştirilmelidir. Bununla birlikte, ihracat amacıyla gelecek yabancı yatırımlara teşvik 
ve alt yapı hizmetlerinde öncelik verilerek DYY'nin ihracat üzerindeki etkisi artırılmalıdır. Son olarak ise, Türkiye karşılaştırmalı üstünlükleri olan sektörlere ve bağlantı seviyesi yüksek olan sektörlere daha fazla DYY girişi elde etmeye uğraşmalıdır.

\section{KAYNAKÇA}

AĞIR, H. ÖZBEK, S. \& TÜRKMEN, S. (2020). “Türkiye'de Cari İşlemler Dengesinin Dinamikleri: VAR Analizi”, Maliye Araştırmaları Dergisi, 6 (2): 57-66.

ACARAVCI, A. \& AKYOL, M. (2017). “Türkiye'de Doğrudan Yabancı Yatırımlar, Dış Ticaret ve Ekonomik Büyüme İlişkisi”, Uluslararası Ekonomi ve Yenilik Dergisi, 3 (1): 17-33.

AKMAN, A. S. (2019). Doğrudan Yabancı Yatırımların Türkiye'nin İhracat Performansı Üzerindeki Etkisi, Uludağ Üniversitesi Sosyal Bilimler Enstitüsü Yüksek Lisans Tezi, Bursa.

ALTINTAŞ, H. (2009). "Türkiye'de Doğrudan Yabancı Sermaye Girişi ve Dış Ticaret Arasındaki İlişkinin Ekonometrik Analizi: 1996-2007”, Ankara Üniversitesi SBF Dergisi, 19(2): 145-156.

BARRIOS, S., GÖRG, H. \& STROBL, E. (2005). "Foreign Direct Investment, Competition and Industrial Development In The Host Country", European Economic Review, 49(7): 1761-1784.

BAYAR, M. (2013). Doğrudan Yabancı Yatırımlar, Ekonomik Büyüme ve Dış Ticaret İlişsisi: Türkiye Örneği, Bülent Ecevit Üniversitesi Sosyal Bilimler Enstitüsü Yüksek Lisans Tezi, Zonguldak.

BRUEGEL, (2012). Real Effective Exchange Rates For 178 Countries: A New Database, BRUGEL Working Paper Series, 1-35.

BOZDAĞLIOĞLU, E.Y. (2010). Türkiye'ye Gelen Doğrudan Yabanc1 Sermaye Yatırımlarının Türkiye'nin İhracat Performansına Etkilerinin Analizi, Adnan Menderes Üniversitesi Sosyal Bilimler Enstitüsü Doktora Tezi, Aydın.

CANPOLAT, M. 2019. Doğrudan Yabancı Yatırımlar ve Dış Ticaret İlişkisi: BRICS-T Ülkeleri Örneği, Çankaya Üniversitesi Üniversitesi Sosyal Bilimler Enstitüsü Yüksek Lisans Tezi, Ankara.

CEYLAN, R. \& BAŞER, S. (2014). “Türkiye'de Petrol Tüketimi ile Reel GSYİH Arasındaki Uzun Dönem İlişkinin Johansen Eşbütünleşme Yöntemi İle Analiz Edilmesi”, Business and Economics Research Journal, 5 (2): 47-60.

DELİCE, G. \& BİROL, Y. E. (2011). "Dolaysız Yabancı Sermaye Yatırımları ve Dış Ticaret Bilançosu: Türkiye Üzerine Bir Uygulama”, Uludağ Üniversitesi İktisadi ve İdari Bilimler Fakültesi Dergisi, 30 (2): 1-28.

DEMİRGİL, B. (2019). “Türkiye'de Enflasyonun Belirleyicileri Üzerine Uygulamalı Bir Çalışma", Journal of International Management Educational and Economics Perspectives, 7 (1): 13-21. 
DICKEY, D. A. \& FULLER, W. A. (1981). "Likelihood Ratio Statistics for Autoregressive Time Series with a Unit Root", Econometrica, 49: 1057-1072.

DOĞANAY, M. A. \& DEĞER, M. K. (2017). "Yükselen Piyasa Ekonomilerinde Doğrudan Yabancı Yatırımlar ve İhracat İlişkisi: Panel Veri Eşbütünleşme Analizleri (19962014)", Çankırı Karatekin İktisadi ve İdari Bilimler Dergisi, 7(2): 127-145.

EKHOLM, K., FORSLID, R. \& MARKUSEN, J. (2003a). "Export Platform Foreign Direct Investment", Cerge-Ei, 1-42.

EKHOLM, K., FORSLID, R. \& MARKUSEN, J. (2003b). "Export Platform Foreign Direct Investment", NBER Working Paper Series, 1-44.

GÖÇER, İ., BULUT, S. \& DAM, M. M. (2012). “Doğrudan Yabancı Yatırımların Turkiye’nin İhracat Performansina Etkileri: Ekonometrik Bir Analiz", Business and Economics Research Journal, 3(2): 21-40.

GÖKÇE, T. O. (2018). BRIC Ülkelerinde ve Türkiye'de Doğrudan Yabancı Yatırımların Makroekonomik Etkileri, İstanbul Ticaret Üniversitesi Dış Ticaret Enstitüsü Yüksek Lisans Tezi, İstanbul.

GRANGER, C.W.J. (1969). "Investigating Causal Relation By Econometric and CrossSectional Method", Econometrica, 37: 424-438.

GREENAWAY, D., SOUSA, N. \& WAKELIN, K. (2004). "Do Domestic Firms Learn To Export From Multinationals?”, European Journal of Political Economy, 20 (4): 10271043.

GUJARATI, D. (1999). Temel Ekonometri, Literatür yayıncılık, (Çevirenler: Ümit ŞENESEN, Gülay Günlük ŞENESEN), İstanbul.

GÜR, N. (2014). Doğrudan Yabancı Yatırımların Yerli Şirketler Üzerine Etkileri, Müsiad Araştırma Raporları.

İMSAD (Türkiye İnşaat Malzemeleri Sanayicileri Derneği), (2019). Türkiye IMSAD Aralık Aylık Sektör Raporu, İstanbul.

JOHANSEN, S. (1991). "Estimation and Hypothesis Testing of Cointegration Vectors in Gaussian Vector Autoregressive Models", Econometrica, 59 (6): 1551-1580.

KALKINMA BAKANLIĞI, (2018a). On Birinci Kalkınma Planı: Üretim ve Dış Ticaret İlişkisi, Çalışma Grubu Raporu, Ankara.

KALKINMA BAKANLIĞI, (2018b). On Birinci Kalkınma Planı: Lojistik Hizmetlerinin Gelişimi, Çalışma Grubu Raporu, Ankara.

KARLUK, R. (2013). Uluslararası Ekonomi Teori Politika, Beta Basım, İstanbul.

KARAGÖZ, M. \& KARAGÖZ, K. (2006). “Türk Ekonomisinde İhracat ve Dogrudan Yabanc1 Yatırım İlişkisi: Bir Zaman Serisi Analizi”, Ekonomik ve Sosyal Arastırmalar Dergisi, 3 (1): $117-126$

KASTRATOVIĆ, R. (2020). "The Impact of Foreign Direct Investment on Host Country Exports: A Meta-Analysis”, World Economy, (43): 3142-3183. 
KILINÇER, B. (2019). Doğrudan Yabancı Yatırım Girişlerinin Türkiye'nin Finansal Göstergeler Üzerine Etkileri, İnönü Üniversitesi Sosyal Bilimler Enstitüsü Doktora Tezi, Malatya.

KNELLER, R. \& PISU, M. (2004). "Export-oriented FDI in the UK", Oxford Review of Economic Policy, 20 (3): 424-439.

KNELLER, R. \& PISU, M. (2005). "Industrial Linkages and Export Spillovers from FDI", World Economy, 30 (1): 105-134.

KOCABIYIK, T. (2016). "Johansen Eşbütünleşme Testinde Karar Aşamalarının Analizi”, Süleyman Demirel Üniversitesi Sosyal Bilimler Enstitüsü Dergisi, 40-50.

KOÇ, Ö. (2015). Türkiye'de Doğrudan Yabancı Yatırımlar ile İhracat ve İthalat Arasındaki Nedensellik, Karadeniz Teknik Üniversitesi Sosyal Bilimler Enstitüsü Yüksek Lisans Tezi, Trabzon.

KURNAZ, T. (2014). 1980 Sonrası Türkiye Ekonomisi ve Dış Ticaretin Gelişimi, Çağ Üniversitesi Sosyal Bilimler Enstitüsü Yüksek Lisans Tezi, Mersin.

MAJEED, M. \& AHMAD, E. (2007). "FDI and Exports in Developing Countries: Theory and Evidence", The Pakistan Development Review, 46(4): 735-750.

NAIR-REICHERT, U. \& WEINHOLD, D. (2001). “Causality Tests For Cross-Country Panels: A New Look At FDI and Economic Growth in Developing Countries", Oxford Bulletin of Economics and Statistics, 63(2): 153-171.

NJONG, A. M. \& RAYMOND, T. (2011). "Investigating The Effects Of Foreign Direct Investment On Export Growth In Cameroon". International Journal Of Current Research, 3 (5): 184-191.

OECD, Ekonomik Kalkınma ve İş Birliği Örgütü, "FDI Restrictiveness Index”, https://data.oecd.org/, 14.09.2021.

ÖĞÜT, A., MUCUK, M. \& DEMİRSEL, M. T. (2014, October). Foreign Direct Investment and Export In Turkey: A Cointegration Analysis, 12th International Academic Conference, Prague.

ÖZBOSTANCI，F. (2016). Bric Ülkeleri ve Türkiye’ye Yapılan Doğrudan Yabanc1 Yatırımların Ülkelerin İhracatı Üzerine Etkileri: Panel Veri Analizi, Süleyman Demirel Üniversitesi Sosyal Bilimler Enstitüsü Yüksek Lisans Tezi, Isparta.

ÖZCAN, S. E. (2007). Kamu Açık ve Borçlarının Sürdürülebilirliği: 1970-2005 Türkiye Örneği, Kütahya Dumlupınar Üniversitesi Sosyal Bilimler Enstitüsü Doktora Tezi, Kütahya.

ÖZDEMİR, S. (2018). Gayrimenkul Sektöründeki Yasal Düzenlemelerin Yabancı Yatırımcılar Üzerine Etkisi, İstanbul Gelişim Üniversitesi Sosyal Bilimler Enstitüsü Yüksek Lisans Tezi, İstanbul.

PEKER, O. (2009). “Türkiye'deki Cari Açık Sürdürülebilir mi? Ekonometrik Bir Analiz”, Kocaeli Üniversitesi Sosyal Bilimler Dergisi, (17): 164-174. 
PERRON, P. (1989). "The Great Crash, the Oil Price Shock, and the Unit Root Hypothesis", Econometrica, 57 (2): 1361-1401.

SELIMI, N., REÇI, K. \& SADIKU, L. (2016). “The Impact of Foreign Direct Investment on the Export Performance: Empirical Evidence for Western Balkan Countries", ILIRIA International Review, 6 (1): 57-66.

ŞEN, A. \& KARAGÖZ, M. (2005). “Türkiye'deki Doğrudan Yabancı Sermaye Yatırımlarının Büyüme ve İhracata Etkisi”, Sosyal Siyaset Konferansları Dergisi, (50): 1063-1076.

TAPŞIN, G. (2016). “The Relationship Between Foreign Direct Investment, Export and Economic Growth In Turkey", Journal of Business Managemnet and Economics, 4 (5): 1-6.

TCMB, Türkiye Cumhuriyet Merkez Bankası, “Ödemeler Dengesi İstatistikleri”, https://www.tcmb.gov.tr/, 17.09.2021.

TEMIZ, D. \& GÖKMEN, A. (2009, June). Foreign direct investment and export in Turkey: The period of 1991-2008, Econ Anadolu 2009: Anadolu International Conference in Economics.

TERZİ, H. \& PATA, U. K. (2016). "Doğrudan Yabancı Yatırımlar ve Dış Ticaret Arasındaki İlişkinin Analizi: Türkiye Deneyimi”, Erciyes Ünivesitesi İktisadi ve İdari Bilimler Dergisi, (48): 167-184.

TÜRKMEN, S. ÖZBEK, S. \& KARAKUŞ, M. (2018). “Türkiye'de Elektrik Tüketimi ve Ekonomik Büyüme Arasındaki İlişki: Ampirik Bir Analiz”, Kahramanmaraş Sütçü İmam Üniversitesi İktisadi \& İdari Bilimler Fakültesi Dergisi, 8 (2): 129-142.

UNCTAD (Birleşmiş Milletler Ticaret ve Kalkınma Konferansı), (2019). World Investment Report 2019 Special Economic Zones, İsviçre.

UNCTAD, Birleşmiş Milletler Ticaret ve Kalkınma Konferansı, "Doğrudan Yabancı Yatırım”, https://unctadstat.unctad.org, 17.09.2021.

WTO, Dünya Ticaret Örgütü, “D1ş Ticaret”, https://data.wto.org/, 17.09.2021.

WTO (Dünya Ticaret Örgütü), (2019). World Trade Statistical Review 2019, Switzerland.

VERNON, R. (1966). "International Investment and International Trade in the Product Cycle", The Quarterly Journal of Economics, 80 (2): 190-207.

YILANCI, V. (2009). "Yapısal Kırılmalar Altında Türkiye için İşsizlik Histerisinin Sınanması", Doğuş Üniversitesi Dergisi, 10 (2): 324-335.

YILMAZER, M. (2010). "Doğrudan Yabancı Yatırımlar, Dış Ticaret ve Ekonomik Büyüme İlişkisi: Türkiye Üzerine Bir Deneme", Celal Bayar Üniversitesi Sosyal Bilimler Dergisi, 8 (1): 241-260.

ZHANG, K. H. (2005, June). How Does FDI Affect a Host Country's Export Performance? The Case of China, International conference of WTO, China.

ZHANG, K. H. \& SONG, S. (2000). "Promoting Exports The Role Of Inward FDI in China", China Economic Review, 11 (4): 385-396. 
ZIVOT, E. \& ANDREWS, D.W.K. (1992). "Further Evidence on the Great Crash, the Oil Price Shock and the Unit Root Hypothesis", Journal of Business and Economic Statistics, 10(3): 251-270. 